\title{
Primary peritonitis in children and adults
}

\author{
T. G. ARMITAGE \\ M.B., Ch.B., F.R.C.S.Ed. \\ R. C. N. Williamson \\ M.Chir., F.R.C.S.
}

University Department of Surgery, Bristol Royal Infirmary, Bristol BS2 $8 \mathrm{HW}$

\begin{abstract}
Summary
Five cases of primary peritonitis are presented, with a sixth related case of pneumococcal peritonitis secondary to a ruptured ovarian cyst. The patients comprised 4 young girls who recovered, and 2 elderly females who died. Pneumococci were isolated in 3 patients; no organism was found in the other 3 . One case of primary measles peritonitis has no apparent precedent.
\end{abstract}

KEY WORDS: peritonitis, pneumococcus, measles.

\section{Introduction}

Peritonitis without an underlying intraperitoneal lesion is uncommon at any age nowadays. It usually presents in childhood, with the pneumococcus as the infecting organism, and it is nearly always mistaken for acute appendicitis. Primary peritonitis has also been described as a complication of the nephrotic syndrome or cirrhosis hepatis, and non-pneumococcal organisms have increasingly been isolated.

\section{Patients}

The 6 patients were admitted as emergencies between 1975 and 1979 to one of three Bristol Hospitals: the Royal Infirmary, the Royal Hospital for Sick Children and Southmead General Hospital. There were 4 children and 2 adults, and all were female. They may be conveniently grouped into three pairs: girls with classical pneumococcal peritonitis, girls with sterile peritonitis of possible viral origin, and adults with haematogenous peritonitis. The clinical details are summarized below and in Table 1 .

Both children with pneumococcal peritonitis presented with the clinical features of generalized peritoneal irritation and harboured copious quantities of odourless, turbid fluid within the abdominal cavity. Immediate microscopy of the peritoneal exudate revealed numerous Gram-positive diplococci, and a pure growth of Streptococcus pneumoniae was obtained on subsequent culture. Postoperative swabs of throat, urine and faeces were negative for pneumococci. In each case the resected appendix was histologically normal, apart from mild peritoneal reaction. Parenteral ampicillin therapy was started peroperatively, and both girls made a prompt recovery.

The two children with sterile peritonitis were similar to the previous pair with regard to age, sex, clinical presentation and laparotomy findings. However, bacterial cultures of the peritoneal fluid were sterile, as were postoperative samples of blood and sputum. As before, appendicectomy was carried out, antibiotics were given and abdominal signs quickly resolved. In one child an upper respiratory tract infection 2 weeks before admission raised the possibility of a viral cause for the ensuing peritonitis. The other girl developed a diffuse morbilliform rash 4 days after operation, followed by florid measles with Koplik spots and conjunctivitis. Histological examination of the appendix had shown no active inflammation but the classical giant cells (Warthin-Finkeldy) of measles (Fig. 1).

Two elderly women with probable haematogenous peritonitis and concomitant ovarian lesions developed postoperative chest infections and later died from cardiovascular complications. Neither patient had any overt intra-abdominal cause to explain their generalized purulent but odourless peritonitis. As in the children, the abdominal viscera in each case (appendix, ovary, uterine tube) showed histological evidence only of pyogenic serositis. The first case was of primary peritonitis complicating ovarian carcinomatosis and malignant ascites; the causative organism was not isolated. In the second case pneumococcal pneumonia probably preceded septicaemia and secondary infection of a benign papillary cystadenoma of the right ovary, which subsequently ruptured; the peritoneal fluid was teeming with pneumococci.

\section{Discussion \\ Incidence}

In children primary peritonitis comprises about $2 \%$ of all abdominal emergencies (Cole, 1937; Fowler, 
TABLE 1. Clinical details

\begin{tabular}{|c|c|c|c|c|c|c|}
\hline Case & $\begin{array}{c}\text { Age } \\
\text { (years) }\end{array}$ & $\begin{array}{l}\text { Pre-operative } \\
\text { diagnosis }\end{array}$ & Associated conditions & $\begin{array}{l}\text { Culture of } \\
\text { peritoneal } \\
\text { fluid }\end{array}$ & $\begin{array}{l}\text { Postoperative } \\
\text { complications }\end{array}$ & Definitive diagnosis \\
\hline 1 & 7 & $\begin{array}{l}\text { Perforated } \\
\text { appendicitis }\end{array}$ & $\begin{array}{l}\text { Rubella } 2 \text { months } \\
\text { earlier }\end{array}$ & Pneumococci & Transient pleurisy & $\begin{array}{l}\text { Primary pneumococcal } \\
\text { peritonitis }\end{array}$ \\
\hline 2 & 9 & $\begin{array}{l}\text { Perforated } \\
\text { appendicitis }\end{array}$ & - & Pneumococci & Nil & $\begin{array}{l}\text { Primary pneumococcal } \\
\text { peritonitis }\end{array}$ \\
\hline 3 & 8 & $\begin{array}{l}\text { Perforated } \\
\text { appendicitis }\end{array}$ & $\begin{array}{l}\text { Respiratory infection } \\
2 \text { weeks earlier }\end{array}$ & Sterile & Nil & $\begin{array}{l}\text { Primary peritonitis } \\
\text { ? viral }\end{array}$ \\
\hline 4 & 9 & $\begin{array}{l}\text { Acute } \\
\text { appendicitis }\end{array}$ & - & Sterile & Measles & $\begin{array}{l}\text { Primary peritonitis } \\
\text { ? viral (morbilli) }\end{array}$ \\
\hline 5 & 71 & $\begin{array}{l}\text { Peritonitis } \\
\text { ? cause }\end{array}$ & $\begin{array}{l}\text { Carcinoma right ovary } \\
\text { Carcinomatosis } \\
\text { peritonei }\end{array}$ & Sterile & $\begin{array}{l}\text { Pneumonia, } \\
\text { Stroke } \\
\text { Death at } 1 \text { month }\end{array}$ & $\begin{array}{l}\text { Primary peritonitis } \\
\text { complicating malignant } \\
\text { ascites }\end{array}$ \\
\hline 6 & 76 & $\begin{array}{l}\text { Perforated } \\
\text { diverticulitis }\end{array}$ & $\begin{array}{l}\text { Benign cyst right ovary } \\
\text { Acute salphingo- } \\
\text { öophoritis }\end{array}$ & Pneumococci & $\begin{array}{l}\text { Pneumonia, } \\
\text { Congestive heart failure } \\
\text { Death at } 10 \text { days }\end{array}$ & $\begin{array}{l}\text { Pneumococcal peritonitis } \\
\text { secondary to metastatic } \\
\text { infection of ovarian cyst }\end{array}$ \\
\hline
\end{tabular}

1971), and in one series as many as $14 \%$ of cases of diffuse peritonitis (McDougall, Izant and Zollinger, 1975). In adults the disease seems much rarer, although isolated cases of pneumococcal peritonitis have been reported in adolescence (McFarlane et al., 1979 ) and young adulthood (Friedland and Harris, 1970). Many of the childhood cases (11-59\%) have affected patients with nephrotic syndrome (Cole, 1937; Fowler, 1971; Pahmet, 1940). In both children and adults, primary peritoneal infection is an accepted complication of cirrhosis hepatis (Finlayson and Roth, 1964; Conn, 1964; Kerr, Pearson and Read, 1963; Epstein, Calia and Gabuzda, 1968). Streptococcal peritonitis has also been reported in association with a low serum albumin in young women with anorexia nervosa and purgative abuse (Khoury and Wall, 1982).

Normal girls are much more likely than boys to develop primary peritonitis (Cole, 1937; Fowler, 1971; Pahmet, 1940; McCartney and Fraser, 1922), but the sex distribution is more equal in patients with nephrotic syndrome (Cole, 1937; Pahmer, 1940). In adults with cirrhosis, the childhood sex incidence is reversed. In three combined series (Finlayson and Roth, 1964; Conn, 1964; Kerr et al., 1963) 13 of 19 patients were male, presumably because cirrhosis is commoner in men. All 6 patients in our series were female.

\section{Bacteriology}

The causative organisms of primary peritonitis appear to have changed character during the last 60 years. Most early series implicated Streptococcus pneumoniae as the major childhood pathogen (Cole, 1937; McCartney and Fraser, 1922), although peritonitis caused by $S$. pyogenes was also recognized. Subsequent reports, notably Fowler's large Australian series (1971), have shown a decline in pneumo- coccal isolates from 50/72 organisms before 1956 to $6 / 33$ organisms thereafter. This change corresponds to a decline in endemic pneumococcal infection? owing to effective antimicrobial therapy. By contrast, $\overrightarrow{\text {, }}$ Gram-negative organisms have increasingly beeno isolated (McDougall et al., 1975; Speck, Dresdale and McMillan, 1974), especially in cirrhotics; yet pneuき mococci may infect ascitic fluid (Epstein et al., 1968) $\vec{\bullet}$ In many cases no causative organism can be fou and this applied to 3 of our 6 patients. Cultures from the other 3 grew pneumococci.

\section{Aetiology and pathogenesis}

Isolation of $S$. pneumoniae from the vagina in earlyo series supported the general belief that pneumococca peritonitis was caused by ascending infection from the genital tract in little girls (McCartney and Fraser, 1922). The declining incidence of the disease mighto reasonably be attributed to improved standards of hygiene and general health.

Other possibilities for the source of infectiond include haematogenous or transdiaphragmatie spread from other sites, usually the respiratory tract, 0 and transmural spread through the intestine (Cole, 1937). Two of our children had had recent upper respiratory infections. In one of the adults pneumo- $\rightarrow$ coccal septicaemia secondary to pneumonia may have preceded infection of an ovarian cyst and thereafter, by an unusual sequence, metastatic peri- $\sigma$ tonitis. Another possible site for primary infection $\tilde{N}$ the urinary tract, was implicated in 10 of 26 cases in a more recent report (McDougall et al., 1975). Theo source of infection remains obscure in many caseso without an overt focus and with negative peritonea cultures.

The relative frequency of peritonitis in the nephro- 0 tic syndrome and cirrhosis suggests that ascitic fluido is a good culture medium, in which bacteria from 


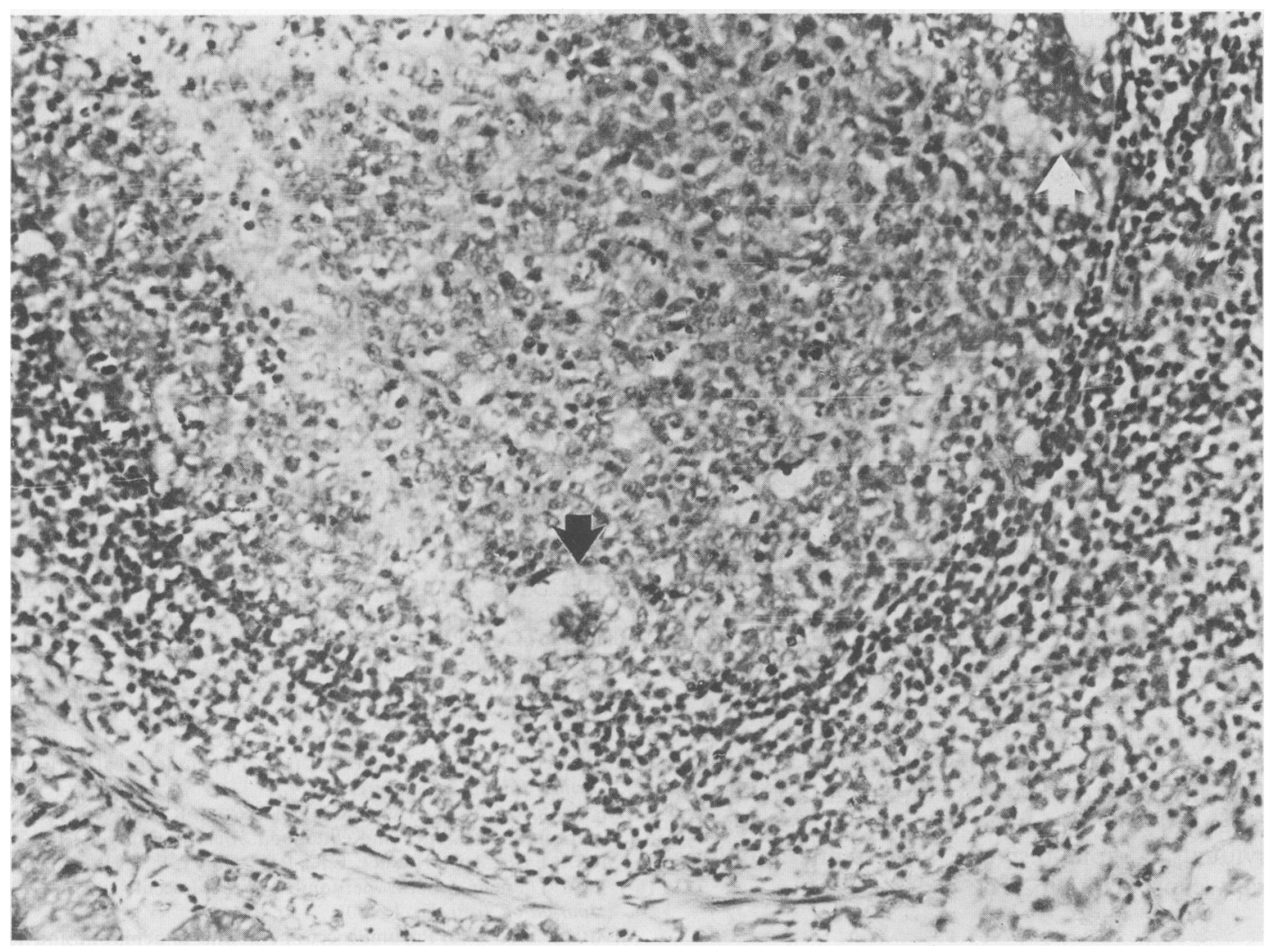

FIG. 1. Histological section through the appendix in case No. 4, showing a submucosal lymphoid follicle containing two Warthin-Finkeldy giant cells (arrowed).

whatever origin may lodge and multiply. Hypoproteinaemia and an impaired immunological capacity may also be contributory (Khoury and Wall, 1982). We have described one case of peritonitis complicating malignant ascites of ovarian origin. In cirrhosis, peritoneal infection has been ascribed both to decreased hepatic filtration of intraportal organisms and to contamination by abdominal paracentesis (Kerr et al., 1963). In the nephrotic syndrome, hypercoagulability (Futrakul, 1978) might cause splanchnic ischaemia and thus secondary infection of the peritoneum (Fowler, 1971).

A possible viral aetiology of primary peritonitis was postulated by Fowler (1971), who isolated an ECHO (type 4) virus from a mesenteric node in one patient and rubella from the peritoneal exudate and throat of another. Both cases were accompanied by rising antibody titres in convalescent sera. Viral infection could account for some 'sterile' cases of primary peritonitis, as in two of our patients. Indeed the evidence is strong in the child with clinical and pathological evidence of measles. Although her appendix was not inflamed; it showed typical Warthin-Finkeldy giant cells. Measles has been recognized in association with acute appendicitis (Whyte and MacBain, 1977) but not previously as a cause of primary peritonitis. A well-defined syndrome of infectious peritonitis resulting from coronavirus infection has been described in the cat (Horginek and Osterhaus, 1979).

\section{Clinical presentation and management}

Despite early reports to the contrary (Cole, 1937; McCartney and Fraser, 1922), it must be difficult to distinguish the clinical features of primary peritonitis from those of perforated appendicitis or other forms of diffuse peritonitis (Golden and Shaw, 1972). All our cases had a firm, though mistaken, pre-operative diagnosis.

It is reasonable to suspect primary peritonitis in patients with pre-existing nephrosis or cirrhosis, who develop signs of peritoneal irritation or whose general condition deteriorates. The diagnosis may 
then be confirmed by paracentesis, allowing bacteriological examination of the peritoneal fluid and treatment with the appropriate antibiotic (Kerr et al., 1963). Otherwise the diagnosis should be suspected at laparotomy, when diffuse peritonitis is found in the absence of any obvious intraperitoneal lesion. An initial incision in the right iliac fossa should be extended to allow adequate examination of the abdominal viscera and the exclusion of other atypical causes of peritonitis, such as occult perforation of the intestine by a foreign body or through a diverticulum. Tuberculous peritonitis may sometimes present acutely; the diagnosis is suggested by the presence of serosal tubercles, enlarged mesenteric nodes, a caecal tuberculoma or an extra-abdominal focus of tuberculous infection (Khoury, Payne and Harvey, 1978).

Diagnostic clues at laparotomy may be provided by the very extent of peritoneal infection, compared with the patient's general health, and by the odourless nature of the pus. In this situation we have found that an immediate Gram strain of the peritoneal fluid can be reassuring (Golden and Shaw, 1972), and it may dictate the initial choice of antibiotic. Laparotomy also permits saline lavage of the peritoneal cavity, although the value of drainage is in doubt (McDougall et al., 1975). In otherwise healthy individuals a rapid response to systemic antibiotic therapy can be anticipated.

\section{Acknowledgments}

We are grateful to the consultant surgeons who have allowed details of their cases to be published, and to Dr P. A. Burton, Consultant Histopathologist at Southmead Hospital, who supplied the photomicrograph.

\section{References}

Cole, W.H. (1937) Pneumococcus peritonitis. Surgery, 1, 386.

CONN, H.O. (1964) Spontaneous peritonitis and bacteremia Laennec's cirrhosis caused by enteric organisms. Annals of Internal Medicine, 60, 568.

Epstein, M., Calia, F.M. \& Gabuzda, G.J. (1968) Pneumococca peritonitis in patients with post-necrotic cirrhosis. New Englan Journal of Medicine, 278, 69.

FINLAYSON, G. \& ROTH, H.P. (1964) Acute abdominal emergencie in patients with cirrhosis. Archives of Surgery, 88, 947.

FOWLER, R. (1971) Primary peritonitis: changing aspects 1956-1970 Australian Paediatric Journal, 7, 73.

Friedland, J.A. \& HARRIS, M.N. (1970) Primary pneumococcaP peritonitis in a young adult. American Journal of Surgery, 119, 737.

FuTRaKUL, P. (1978) Primary peritonitis syndrome: A state of hypercoagulability in the nephrotic syndrome. Journal of the Medical Association of Thailand, 61, 268.

Golden, G.T. \& SHAW, A. (1972) Primary peritonitis. Surgery Gynecology and Obstetrics, 135, 513.

HoRgineK, M.C. \& OSTERHAUS, A.D. (1979) The virology and pathogenesis of feline infectious peritonitis. Archives of Virolog, $59,1$.

KeRR, D.N.S., PEARSON, D.T. \& Read, A.E. (1963) Infection of ascitic fluid in patients with hepatic cirrhosis. Gut, 4, 394.

Khoury, G.A., PAYNe, C.R. \& HARvey, D.R. (1978) Tuberculosis of the peritoneal cavity. British Journal of Surgery, 65, 808.

KHOURY, G.A. \& WALL, R.A. (1982) Streptococcal peritonitic associated with the cathartic colon. British Journal of Surgery, 69 327.

MCCartney, J.E. \& Fraser, J. (1922) Pneumococcal peritonitis British Journal of Surgery, 9, 479.

MCDougall, W.S., IZANT, R.J. Zollinger, R.M. (1975) Prim\& $\overrightarrow{0}$ peritonitis in infancy and childhood. Annals of Surgery, 181, 300

MCFARLANE, A.C., HAMRA, L.K., ReISS-LEVY, E. \& HANSMAN,D: (1979) Pneun ococcal peritonitis in adolescent girls. Me Journal of Australia. 1, 100.

Pahmet, M. (1940) Pneumococcus peritonitis in nephrotic and non nephrotic children. Journal of Pediatrics, 17, 90.

SPECK, W.T., Dresdale, S.S. \& MCMillan, R.W. (1974) Primaryo̊ peritonitis and the nephrotic syndrome. American Journal og Surgery, 127, 267.

WhYTE, A.S. \& MACBAIN, G.C. (1977) Acute appendicitis and $\overline{\overline{0}}$ measles. Journal of the Royal College of Surgeons of Edinburgh, 22,? 428.

(Accepted 21 July 1982) 